\title{
THE COMPARATIVE VALUE OF CARDIAC REMEDIES :
}

\author{
THEODORE C. JANEWAY, M.D. \\ NEW YORK
}

I. INTRODUCTION.

II. EfFects of Digitalis on the Normal Circulation.

III. Drugs in Cardiac Insufficincy with Auricular Fibrillation.

A. Acute, in mitral disease.

$B$. Chronic, in mitral disease.

(a) Strophanthin.

(b) Digitalis.

C. In other rapid, fibrillating hearts.

(a) In aortic disease.

(b) In chronic nephritis.

(c) In myocardial disease.

(d) In paroxysmal tachycardia.

(e) In cases with paroxysmal dyspnea.

(f) In cases with active endocarditis.

IV. Drugs in Cardiac Insufficiexcy with Normal Rhythm.

A. In hypertensive cases.

(a) Digitalis.

(b) Caffein and allies.

$B$. In primary myocardial insufficiency.

$C$. In mitral disease.

$D$. In aortic disease.

E. In failure of the right ventricle.

$F$. In exophthalmic goiter.

V. Drugs in Other Disturbances of Rhythm.

A. In paroxysmal tachycardia.

$B$. In heart block.

C. In extrasytolic irregularity.

VI. Drugs in Angina Pectoris.

VII. The Treatment of Recent Endocarditis and Ixitial Cardiac INSUFFICIENCY.

VIII. Coxclusions.

BibliogRAPHY.

\section{INTRODUCTION}

At an international congress of medicine held in the city where William Harvey announced his discovery of the circulation of the blood, in the land where Withering first made the therapeutic virtues of the foxglove the subject of scientific inquiry, it is fitting that a section presided over by the eminent therapeutist to whom we owe the nitrites should discuss the comparative value of cardiac remedies. Twelve years ago, in a similar discussion before the nineteenth congress of internal

* Report presented before the Section on Therapeutics (Pharmacology), Physio-Therapy and Balneology of the XVII International Congress of Medicine, London, August, 1913. 
medicine at Berlin, Professor Sahli said: "Allein die Handhabung der Digitalis ist eine grosse Kunst, und wie in jeder Kunst, so erreicht man auch hier kaum den Gipfel der Vollendung." No more complete demonstration of this could be afforded than the added knowledge of this very drug which the clinical studies of the twelve intervening years have contributed. The literature of the clinical investigations of cardiac remedies is now so vast that an attempt to give proper credit to the workers in the field is out of the question. I shall therefore ask pardon in advance for my omissions in this respect.

The limitation of the field of inquiry is difficult. Even the digitalis bodies, the cardiac remedies par excellence, have important vascular and nervous actions as well. As far back as 1866, Lauder Brunton pointed out their effect on the arterioles; the subject was subsequently studied exhaustively by Gottlieb and Magnus. This action is quite selective, so that small doses, both of digitalis derivatives and of strophanthin, may dilate the renal, while constricting the intestinal vessels, as Jonescu and Loewi, Kasztan and Fahrenkamp have shown. While Heubner denies that this occurs with therapeutic doses, and Gottlieb himself does not consider it more than highly probable, the studies of Schlayer and Hedinger on the over-irritability of the arteries in experimental nephritis - and in particular the subsequent work of Hedinger - make the strongest presumption in favor of regarding these truly cardiac drugs as at times diuretic, by local vasodilatation in the kidney. This being so, it seems wiser not to exclude from the category of cardiac remedies drugs such as caffein and camphor, whose direct cardiac action is denied by some pharmacologists - Cushny, for instance - and which act mainly on the arteries and vasomotor center. The estimation of the share of heart and vessels in a circulatory disorder is not always possible. I shall therefore consider cardiac remedies rather broadly, as circulatory remedies. I shall give my experience with the various drugs in those disturbances of the circulation in which the heart plays any part, from the standpoint of their efficiency in combating definite perversions of function. From this standpoint we may arrive at greater precision in formulating the indications for and against the several remedies which, with Edens, I believe is the chief difficulty attending their use.

Since the time of Withering, every intelligent physician has recognized the clinical picture of the insufficient heart, with chronic passive congestion of the viscera and edema, as the strictest indication for the use of digitalis or its allies. It has also been clear that the most brilliant results are obtained in the rapid, irregular heart of mitral disease. Perhaps the most important contribution to cardiac pathology and therapy for the past ten years is the proof by Lewis that the delirium cordis of past generations, the pulsus irregularis perpetuis of Hering, the nodal 
rhythm of Mackenzie, are the ventricular manifestations of fibrillation of the auricles. This was made possible by Einthoven, whose string galvanometer has brought the disorders of the heart's rhythm into the range of exact clinical observation; and by the pioneer work of Wenckebach, Hering and Mackenzie in this field. Lewis followed this demonstration by the proof that in man the slowing and steadying of the ventricle under digitalis is due to its action on the junctional tissues, with the production of heart block, just as in von Tabora's experimental studies. Since that time the attention of English and American clinicians and pharmacologists has been focused almost wholly on the effects produced by the digitalis bodies on the cardiac rhythm, because these effects are susceptible of exact demonstration. Other effects entering into the therapeutic action of these drugs have been neglected or ignored. This attitude does not seem so common in Europe. The extreme view was expressed by Cushny in his Harvey lecture for 1911 as follows: "But I think I am safe in stating that we have no definite evidence that digitalis exerts any action apart from the inhibition in these cases of auricular fibrillation, and that the proved fact of inhibition explains all the features observed." At that time Cushny believed digitalis block to be wholly due to vagus inhibition. Recently he has reversed himself (Cushny, Morris and Silberberg). From experiments as to the degree of release after atropin, he concludes that, in normal rhythm, digitalis slowing is usually inhibitory, in fibrillating cases due to direct action on the conducting tissues, direct depression of excitability, or indirect, through improved nutrition of the heart. In a recent discussion on the treatment of non-valvular heart disease he further admits that the effect on the rentricle itself is real, but it is not possible to speak of it with certainty.

Mackenzie expresses himself with somewhat more reserve. His studies of digitalis are a model of thoroughness, and he has been foremost in bringing precision into cardiac therapeutics. He is impressed with the difference in the reaction of individual hearts to the drug, duc at least in part to the nature of the lesion; yet his emphasis is entirely on the disturbance of rhythm, and he thinks little of the gross mechanical defect. In a recent text-book article he states his belief in tone increase under digitalis, though he confesses inability to demonstrate any change in the size of the heart.

Such opinions evidence a healthy scepticism, but also the inadequacy of our present clinical methods for measuring the efficiency of the circulation as a whole. The volume output of the heart we cannot even guess at. The peripherai arterial pressures give us a rough indication of the changes in mean aortic pressure, but vasomotor compensation in man is probably so much more perfect than in the lower animals, that this 
can in nowise be considered a measure of the heart's work. Improved coronary circulation must be an important factor in enhancing the strength of the heart muscle, whenever the aortic circulation is favorably influenced. Up to the present, our simple clinical observation of the redistribution of the blood from the venous to the arterial side of the circulation with shrinking of the swollen liver, absorption of edema with diuresis, and relief of pulmonary stasis and its attendant dyspnea, must be the evidence for the human ventricle of those systolic and diastolic effects of digitalis which are fundamental actions on the isolated heart, as Professor Gottlieb has shown. They must be subjected to searching criticism and such analysis as is possible, and checked by exact observations of rate, rhythm, blood-pressure, water exchanges, and so forth; but they cannot be supplanted by these. For a proper use of cardiac remedies, I agree with Romberg that the emphasis should be on the dynamic condition of the heart's action. Fraenkel's contributions to our knowledge of digitalis therapy have not lost their value because they preceded the era of the polygraph, nor have Huchard's opinions; but they must be amplified and corrected. I would focus your attention, therefore, on the efficiency of the circulation and our ability to influence it.

\section{EFFECTS OF DIGITALIS ON THE NORMAL CIRCULATION}

It seems clear from all pharmacological studies, from such experiments with long-continued digitalis administration as Cloetta's, and from Fraenkel and Schwartz's intravenous strophanthin injections in normal men, that the effects of digitalis on the normal circulation are minimal unless the drug is pushed to the point of intoxication. This fact has often been used as an argument by those who do not believe that digitalis given therapeutically increases the efficiency of the ventricular muscle. I believe, however, that we must recognize that the normal, intact circulation is already working with optimal efficiency and that the perfectly definite systolic and diastolic effects of digitalis on the isolated ventricle are not calculated to enhance this. Whether long-continued administration of digitalis can lead to hypertrophy of the heart, as claimed by Hare and Coplin, no subsequent experiments have determined with any certainty (Cloetta, Gelbart, Wynn).

\section{DRUGS IN CARDIAC INSUFFICIENCY WITH AURICULAR FIBRILLATION}

A. Acute, in Mitral Disease.-The more completely a given circula tory disturbance is dependent on a rapid rate which can be controlled by digitalis, the more brilliant is the therapeutic effect of the drug. The best example of this, in my opinion, is not the extreme cardiac insufficiency with marked chronic passive congestion after long-standing 
auricular fibrillation in mitral disease, but a group of cases which I regard as important to recognize clinically. They are the cases of wellcompensated mitral disease, in which auricular fibrillation with great tachycardia sets in acutely. As a rule, dyspnea is inconspicuous, the symptoms being great exhaustion on exertion, dizziness, and a tendency to syncopal attacks. These are symptoms rather similar to those seen in paroxysmal tachycardia and have some resemblance to Stokes-Adams syndrome. They are presumably due, in the main, to the sudden change in the cerebral circulation. After some days, enlargement and tenderness of the liver appear, and if the condition is unrecognized and therefore untreated, as I have found it to be by the general practitioner, the full-fledged picture of the decompensated mitral heart will then become manifest later. The tachycardia in these patients can be controlled by digitalis within forty-eight hours with complete relief of the symptoms, and under long-continued digitalis medication such patients may maintain a very fair working ability for several years. It is of the highest importance that treatment be instituted before marked dilatation of the right heart and general venous stasis have ensued.

I recognize clearly that the chief factor in determining the brilliant results in these cases is the auricular fibrillation, because, as Mackenzie and Lewis have demonstrated, the His bundle is peculiarly susceptible to digitalis in fibrillating hearts, the seats of old rheumatic mitral disease. On the other hand, it seems to me equally clear that the mitral stenosis makes the rapid, irregular action especially detrimental to the efficiency of the circulation. In fibrillating types of paroxysmal tachycardia, occurring in hearts not the seat of valvular disease, the circulatory disturbance produced is usually much less marked and the therapeutic results are similarly slight. In cases of advanced mitral disease, on the other hand, while the rate may be as easily controlled, secondary changes in Iungs, liver and kidneys already exist, and the extent of the valvular effect is so great as to preclude the re-establishment of even fairly efficient circulation after the rate has been brought to normal. I believe, therefore, that the three elements contributing to the result in these cases are:

1. The existence of a disorder of the rhythm, against which digitalis is absolutely effective.

2. The existence of a valve lesion, the detrimental mechanical effects of which on the circulation are peculiarly heightened by auricular fibrillation.

3. The acute character of the onset of fibrillation in a heart which would have remained well compensated for years, had not the disturbance of rhythm occurred, and which, therefore, must be considered as having had a good right ventricular myocardium. 
B. Chronic, in Mitral Disease.-Next to these acute cases of fibrillation in response to digitalis comes the type picture of gradual cardiac insufficiency, with general venous stasis and edema. Here again, if fibrillation be present, the rapidity and completeness of the functional recovery is in almost direct proportion to the heart rate. In other words, the more these cases conform to the acute type that I have described, the more promptly does the control of the tachycardia by digitalis effect a restitution of function. On the other hand, even in rheumatic mitral disease with fibrillation, if the rate be normal or slow, the effect of digitalis treatment may not be evident until it has been administered for a week or more. In some cases, especially with marked tricuspid regurgitation and liver stasis, it may fail entirely. In other cases the drug acts only after the institution of such accessory measures as the extreme fluid and salt restriction of the Karell diet, which $I$ have found of the utmost value. In some of these patients it is altogether probable that failure is due to defective absorption of the drug given by mouth. Ogawa has shown experimentally how markedly portal stasis interferes with the passage of digitalis from the intestine into the circulation. Meyer discusses this very fully in his recent monograph.

(a) Strophanthin.-It is in these cases of extreme secondary tricuspid regurgitation with pulsating liver that strophanthin intravenously seems the ideal method of administration. My personal experience with it has not been great. I have perhaps been backward in adopting it because of the excellent results that I can usually obtain by the Karell diet. Digitalis following this usually acts with great promptness, even where it has failed before. However, the admirable results obtained with strophanthin by Fraenkel and Schwartz, Fraenkel, Danielopolu, and Bailey, incline me to resort to it more frequently.

The indications, according to Fraenkel and Schwartz, are: (1) In all severe, threatening cardiac insufficiency, dependent on primary cardiac, not vascular or renal, disease; (2) in those cases of subacute and chronic cardiac insufficiency where the patient is so ill that one desires to relieve him in less than forty-eight hours, the time required for effects by mouth; and (3) where the condition of the stomach or bowel, preceding surgical operation, etc., makes internal administration difficult, or where idiosyncrasy to other preparations exists. I am not prepared to adopt the use of strophanthin in chronic cases, except where the existence of very urgent symptoms makes haste imperative, or where portal stasis makes failure with digitalis likely. I agree with Romberg in this respect. In the urgent cases, free venesection is a most important adjuvant measure. When such patients enter a hospital, it must always be remembered that they may have had previous, protracted ambulatory treatment with digitalis. If strophanthin in full doses is then 
administered, the summation of this on a small amount of digitalis already fixed in the heart may produce fatal results. Hatcher and Bailey, the most careful students of strophanthin in America, have made this point clear. That in such cases one must wait, as Romberg insists, from ten to fourteen days after the last dose by mouth was given, does not seem to me imperative if digitalis effects on the general circulation and the heart rhythm are found to be absent. It is clear, however, that a small initial dose should be given, and its effect controlled by graphic record of the rhythm. In general practice, however, great caution is wise. Deaths have occurred after strophanthin which I do not believe can be laid to its use, but Chauffard and Troisier's case was clearly a poisoning, and Agassiz's possibly so.

As to the dose, Hatcher and Bailey, and Bailey, have proved that the crystalline g-strophanthin of Thoms, or ouabain, is most certain, and has twice the strength of the amorphous strophanthin of Boehringer or Merck, which is chiefly used in Europe. The dose should not exceed $0.5 \mathrm{mg}$. in twenty-four hours, and should not be repeated without careful observation of its effects. Hatcher advocates a cat-unit standard equal to $0.1 \mathrm{mg}$. of ouabain. The intravenous dose of any strophanthin should not exceed five such cat-units.

(b) Digitalis.- The choice of a preparation of digitalis is, to my mind, largely a matter of taste, provided the one used is known to be effective. For this reason it has been and is the subject of bitter controversy, into which I shall not enter. It is clear that physiological standardization is in every way desirable, but the recent work of Schmiedeberg and of Holste casts doubt on the absolute value of the frog-unit from year to year. Standardization alone will not ensure a reliable product after the apothecary has had it on his shelves. The method of preservation is all-important, as Focke has demonstrated. Given reliable leaves, my personal preference has always been for the infusion, and Dixon's critical review of the subject confirms my opinion. Gottlieb and Ogawa found the infusion absorbed better from the bowel than the powdered leaf. My experience with it, and my father's before me, have been so favorable that I should require strong evidence to make me change. When away from a known supply of good leaves, however, I have come to advocate digipuratum as a uniform and efficient preparation, even after it has been kept for some time. The question of gastric irritation seems to me of little importance, for I rarely see vomiting, except as a later central effect. In America digalen also has been used extensively, but I have not found it reliable, some samples being inert when sold. It is ordinarily used in too small a dose, through a mistaken idea of its strength. It is too irritant for subcutaneous use. The pure digitoxin used in France, Nativelle's crystallin digitalin, I have had no experience with. At 
the present day the choice of a preparation, I believe, should lie between standardized leaves, given in powder, as infusion, or as tincture; or digipuratum by mouth, with the only other form of administration the intravenous injection of one of the strophanthins, preferably ouabain. Hatcher's work leaves no room for doubt that, because of its extreme variability of absorption, strophanthus should never be administered orally. One should adhere to the use of a single satisfactory preparation and know it thoroughly, rather than experiment with many, and should allow others to be guided equally by their experience.

As to dosage, I have not found the large doses used by Mackenzie and Cushny to be necessary. I prefer a moderate dose, equivalent to not over $0.1 \mathrm{gm}$. (11/2 gr.) of the leaves every four hours, which will give definite slowing of the pulse and diuresis in forty-eight hours in rapid fibrillating cases. This dose I continue until the pulse falls to near 60 or becomes bigeminal; failing this, until absorption of edema is complete, or nausea, vomiting, headache or other toxic symptoms ensue. As a rule, $I$ avoid these. A most important evidence of favorable action, which Prof. W. B. James has made of great use in the wards of the Presbyterian Hospital, is the graphic record of a simultaneously recorded heart-rate and radial pulse-rate. In rapid fibrillating hearts, the difference, which we call pulse deficit, is usually great; but with digitalis slowing, the two curves approach each other, and may finally correspond. When any of these evidences of full therapeutic action is obtained, the drug is stopped and not resumed until increasing rate or pulse deficit, or disappearance of coupled beats, show the heart to be escaping from its influence, which usually occurs in from five to ten days. Then one-half or three-quarters of the daily amount given before will control all symptoms.

In all fibrillating cases with a tendency to rapid rate, after the original digitalis course, I believe the indications for continued, so-called chronic digitalis treatment are absolute. To me they are as absolute as for continued thyroid administration in myxedema. The efficiency of such hearts depends largely on the maintenance of a normal rate. A normal rate can be obtained by perpetuating the right degree of digitalis block. Sometimes this is optimal when the coupled beats appear, but the limit of dosage has then been reached, and the wiser course in ambulant patients is to keep just below that point, with the intermission of a few days every two weeks. Each case must be considered individually, as in determining the tolerance of a diabetic for carbohydrate, and then seen from time to time. Serious breakdown may thus be prevented for years, provided the heart can be reasonably safeguarded from excessive demands or a new infection, and the lesion be not progressive. 
On one point I wish to state my personal opinion unequivocally. Failure to obtain satisfactory results from digitalis therapy in the class of cases just discussed is evidence of an inefficient preparation, insufficient dosage, or an improper mode of administration. I agree entirely with Krehl that, whenever digitalis fails, a second, and then a third trial should be made with a drug obtained from another source. Furthermore, I should urge the need in some cases for employing the accessory measures to which I have alluded.

C. In other Rapid, Fibrillating Hearts. (a) In Aortic Disease.While the failure of compensation in hearts the seat of old mitral endocarditis is most commonly associated with a rapid ventricular rate and fibrillation, insufficient hearts with other primary lesions occasionally fall into this category. With aortic disease it is rare, and this is probably one of the reasons why digitalis so frequently fails in aortic hearts, though not the only reason.

(b) In Chronic Nephritis.-In cardiac insufficiency secondary to hypertensive arterial disease, with or without nephritis, fibrillation is also less common. From my personal records, as I shall show subsequently, the response to treatment in these cases is less dependent on the existence or non-existence of fibrillation. I believe this is in part because such rapid rates as in mitral disease are not observed, but also because moderately rapid, irregular action is less detrimental to the delivery of a reasonable minute volume into the aorta against high pressure, than to maintaining the flow through a narrow, unyielding mitral orifice (B. Lewy). The indications for treatment in the nephritic heart, therefore, I shall consider later.

(c) In Myocardial Disease.-Some elderly people whose hearts exhibit clinically primary myocardial insufficiency show a type of fibrillating tachycardia quite similar to the mitral hearts previously described, and their response to digitalis is in my experience favorable. Schrenck has also had good results in cases of primary myocardial weakness. On the other hand, I have seen patients of this same type in whom the rapid, irregular action had existed for several years, practically without cardiac symptoms. Where a relative mitral regurgitation occurs, I am persuaded from my experience that the effect of digitalis is peculiarly favorable.

(d) In Paroxysmal Tachycardia.-So far as my personal experience goes, I have no evidence that paroxysmal tachycardia, associated with fibrillation of the auricles, reacts to drugs in any way differently from the type without fibrillation. I shall therefore consider paroxysmal tachycardia as a single therapeutic problem later.

(e) In Cases with Paroxysmal Dyspnea.-In one other type of case. I have seen digitalis fail completely, in spite of the existence of rapid 
action and fibrillation. That is, where the picture is dominated by severe paroxysms of dyspnea and eventual lung infarcts. Autopsy on a recent, peculiarly instructive case of this kind showed extensive coronary artery disease, with infarction of the heart-wall and intracardiac thrombi as a source of pulmonary embolism. The severity of the lesion of the myocardium in such a case seems adequate explanation for the failure of any drug. The caffein derivatives were equally without effect in this patient.

(f) In Cases with Active Endocarditis.-It is likewise evident that failure to respond to digitalis on the part of a heart the seat of active inflammatory processes, as in subacute and chronic septic endocarditis, can in nowise be expected, even though fibrillation exists. In my experience, a number of the cases of mitral disease in young persons, in which treatment has been of no benefit, have belonged to this category, the disease being a progressive one.

\section{xV. DRUGS IN CARDIAC INSUFFICIENCY WITH NORMAL RHYTHM}

A. In Hypertensive Cases.-When we turn to hearts beating under the influence of the normal pacemaker, the effects of treatment are, as a rule, much less prompt. For this reason it is more difficult to apportion correctly the credit for benefit produced among the varying factors entering into treatment. The influence of prolonged rest, the dietetic régimen, psychic factors, must al] be taken into account before concluding that any drug which has been administered has contributed largely to the result. Nevertheless, in certain cases with normal rhythm, I have seen digitalis followed by as speedy relief of symptoms as in fibrillating cases. This has been particularly true in patients with cardiac insufficiency secondary to prolonged high blood-pressure. This type of disease, considered by many as chronic nephritis, I look on, with Jores and Aschoff, from the standpoint assumed long ago by Gull and Sutton, as cases of primary sclerosis of the small arteries, the kidney being, as a rule, extensively affected, but sometimes escaping entirely.

(a) Digitalis.-When these patients develop the picture of chronic passive congestion of the viscera with edema, digitalis is as clearly indicated as it is in fibrillating mitral hearts. This is the condition called by Sahli Hochdruckstaaung, and my experience is in absolute accord with his, that danger from increase in the blood-pressure is purely fanciful. My cases have frequently shown a moderate fall in pressure with the onset of cardiac weakness; and I always welcome a rise of 20 or $30 \mathrm{~mm}$. under digitalis as evidence of benefit, though the behavior of the pressure is quite too variable to permit of it being used as a guide. This standpoint finds corroboration in the work of Miller, Price, Burnet and Josué and Godlewski. It cannot be too strongly insisted on that dan- 
gerous increase in blood-pressure from digitalis, as used in human beings, is a superstition without any basis of clinical fact. On the contrary, a moderate hypertension, up to perhaps $180 \mathrm{~mm}$. mercury, is a common accompaniment of cardiac insufficiency from any cause. With the readjustment of the circulation under digitalis, the relief of dyspnea and anxiety, and the absorption of edema, the blood-pressure usually falls in a striking manner. Redistribution of blood from the venous to the arterial side of the circulation, not increased arterial and diminished venous pressures, is what digitalis therapy produces in human beings. I believe that these cases stand second to fibrillating mitral cases in the frequency with which one may ameliorate their symptoms by the digitalis series, and this often independently of the existence or nonexistence of fibrillation. A recent report by Schrenck (from Krehl's clinic) shows equally striking success in such patients. The influence on the rate is, as a rule, not very marked, though some slowing may occur. Gallop rhythm has seemed to me rather to favor the action of the drug. Many of these patients have a relative mitral regurgitation, which complicates the mechanical circulatory defect.

In order to study more exactly the frequency of fibrillation in these cases and its relation to digitalis action, I have analyzed my records of 458 private patients with high blood-pressures, seen during the past nine years, about whom I could obtain information in June, 1912. Two hundred and thirteen of these patients have died, 57 of chronic myocardial insufficiency. At the time of my examination, 71 had evidences of cardiac incompetency, but only 8 (11.2 per cent.) had perpetual arrhythmia, of whom 4 responded well to digitalis. Six patients with normal rhythm reacted to the drug equally well, 2 of them brilliantly. Of the 246 patients still living, 25 had insufficient hearts when seen, only 2 ( 8 per cent.) with fibrillation. Such percentages, I feel sure, are below the frequency of fibrillation in mitral valvular disease with decomposition.

There is a possible difference in the type of disease and the reaction to treatment between the well-to-do and the laboring classes, as one may observe in other pathological conditions. An analysis of a group of my ward patients especially studied, shows 63 with insufficient hearts, of whom 24 had fibrillation at some time. Of these 24 , only 7 were patients with nephritis and hypertension uncomplicated by valvular disease; of these, 5 responded to digitalis. Of 12 regular hearts with hypertension, 5 were given digitalis, and only one showed improvement. However, among 75 patients with auricular fibrillation studied electrocardiographically by Dr. Stuart Hart at the Presbyterian Hospital, only 14 had a blood-pressure above $180 \mathrm{~mm}$. Hg. 
In many of these patients, therefore, we cannot attribute the good effect from digitalis to its action on the rate or rhythm, but I am forced to believe that we see in them the ventricular effects, the increase in completeness of systole at the existing blood-pressure. In addition, it is quite possible that the rapid diuresis and absorption of edema occasionally seen are due to the direct vasodilator effect of the drug on the renal arterioles. It is possible also that splanchnic vasoconstriction with a redistribution of the blood, such as digitalis is able to effect in animal experiments, takes place. In any event, the phenomena bear striking witness to wide-spread action on the circulation as a whole, and cannot be interpreted, as in rapid, irregular mitral hearts, merely to the control of rate and rhythm. I have seen a patient of this type who was waterlogged and who had been having nights of suffering in spite of large doses of morphin for weeks, sleep comfortably in three days after taking 2 drams of infusion of digitalis (60 c.c.) every four hours. His dyspnea was relieved and marked diuresis occurred; the edema was completely absorbed in a week; the enlargement of the liver disappeared, and he was able to walk with comfort. He had complete relief for three months.

I should not like to be understood as maintaining that the benefit from digitalis in auricular fibrillation is obtained without any effect on the ventricle other than that depending on the reduction in rate, but only that the latter is the demonstrable and principal effect. Into the underlying, fundamental problem as to why digitalis so much more easily affects rate and rhythm in fibrillating than in non-fibrillating hearts, I cannot enter. It is at the moment the most important problem awaiting solution by the pharmacologists.

(b) Caffein and Allies.-When digitalis alone does not effect prompt improvement in such patients, the caffein diuretics come in as valuable aids. I believe that their chief effect is local, on the kidney circulation. If given intermittently in comparatively small doses, $2 \mathrm{gr}$. of caffein, 10 of diuretin or 3 of theocin, for three doses, and not repeated until one or two days have elapsed, according to the method of Romberg's clinic, they are capable of producing remarkable increase in urinary output, with absorption of edema, not only in cardiac and renal disease, but occasionally even in the ascites of cirrhosis of the liver. The work of Schlayer and the recent work of Mosenthal and Schlayer, ${ }^{1}$ have shown how overdosage of these drugs may reverse the effect on the vessels and result in oliguria. I lay great stress on the method I have outlined as a factor in the success that may be achieved with these purin diuretics.

Besides their effect on the kidney, however, their action in combination with digitalis in certain cases suggests that their well-known

1. Personal communication; will be published shortly. 
property of dilating the coronary arteries may be of therapeutic importance. Braun has recently given an experimental basis for combined digitalis-caffein therapy, and I have a number of case histories which bear testimony to its value. That caffein can ever supplant digitalis in those circulatory diseases in which digitalis is indicated, I do not believe. Miller's interesting study of decompensated nephritic hearts has shown that relief of dyspnea is much more striking with digitalis; theophyllin, on the other hand, produced marked diuresis in many cases, without notably lessening the respiratory distress.

B. In Primary Myocardial Insufficiency.-This condition, without notable increase in pressure, dependent on coronary sclerosis or degenerative muscle changes, may, if it presents the clinical picture of chronic passive congestion and edema, respond to the digitalis bodies. But, again, many cases fail to respond, and it is in these patients particularly that $I$ have seen the undesirable effects of digitalis on the heart rhythm. Such effects are heart block, which in the two cases reported by Taussig, was permanent and serious, but which may be beneficial, as in a case reported by Hewlett; fibrillation, which may then be favorably affected by digitalis; extrasystoles and bigeminal rhythm, which in these cases are usually undesirable, and the pulsus alterans. In a recent case of this type I have seen pulsus alterans regularly produced after digitalis had been given for a few days, and the patient regularly made worse by it. When these patients are refractory to the digitalis drugs, combined digitalis-caffein medication must be tried, or one of the caffein series alone, but the likelihood of benefit is not great. For their paroxysms of dyspnea, nitroglycerin or other nitrite vasodilators may give temporary relief or cut short the attack. In acute edema of the lungs, as seen in such patients, I believe nitroglycerin to be of real service; and caffein hypodermically also helps.

C. In Mitral Disease with Regular Rhythm.-Here, again, drugs rarely act as in the fibrillating cases. Some of these cases, as a number reported by Mackenzie, improve slowly under digitalis, without showing any effect on the heart-rate. In others, sinus arrhythmias, extrasystoles, block, and even pulsus alterans may be produced, accompanied by improvement in some, and not in others. The French clinicians have always held to the value of caffein in these cases, but $I$ have not been convinced of it. Improvement is usually so slow that doubt must exist as to the value of any drug used; but digitalis up to toxic symptoms does seem to improve the dyspnea.

D. In Aortic Disease.-The use of cardiac drugs in aortic disease, aortic insufficiency especially, has been much fought over. Corrigan's dictum that digitalis should never be given has held sway in many minds. I cannot agree with this. In a number of instances.I have seen marked 
and lasting benefit from digitalis in aortic insufficiency, where the clinical picture was that of chronic passive congestion and edema. The French have spoken of this as the mitral stage of aortic regurgitation, and a relative mitral regurgitation is a frequent accompaniment. Huchard held that aortic incompetency was no contra-indication to digitalis. Schrenck reports its successful use in seven out of nine cases. Romberg does not favor it in uncomplicated cases. The frequent failure, and occasional sudden death, seen during its use in aortic insufficiency, were formerly laid to slowing of the heart with attendant increase in the regurgitation during diastole. If the drug is properly used and large doses avoided, however, marked slowing does not occur.

Sahli explains the failure by assuming that aortic hearts do not produce serious symptoms, as a rule, until the mechanical defect has become very extreme. Failure is then rapid. So far as the symptoms which he means are those of general venous stasis, this assumption seems warranted.

Another factor, I believe, may be of predominant importance, namely, that most aortic regurgitation is not a chronic stationary valvular defect, but the result of a progressive disease, syphilitic aortitis, frequently associated with dilatation of the arch and with actual aneurysm. The symptoms in these cases are rarely those of venous congestion. The striking symptoms are paroxysmal in nature, anginoid pain, and attacks of intense dyspepsia. Sudden death, with or without treatment, is common. This is not the type of circulatory disorder in which digitalis can be expected to do good, and I believe that many of the sudden deaths attributed to digitalis are due to the disease itself. Apart from the treatment of these cases with salvarsan, the paroxysms often yield promptly to one of the nitrites. This condition and its treatment have recently been well studied by Longcope. I find that Hoffmann also shares my view that much of the failure of digitalis in such patients is dependent on the nature of the underlying disease. One should also remember the frequent involvement of the coronary arteries in this condition.

So far as the favorable action of digitalis in some cases of aortic insufficiency is concerned, it seems as though the so-called diastolic effects, the increased diastolic distensibility first described by Williams, and recently studied by Werschinin and by W. Straub, as his so-called. "pure negative" effect, would be the action most to be desired, or a combination of this with increased completeness of systole. The production of this type of effect experimentally seems largely a function of the dosage. Such great precision of dosage is at present clinically impossible, but it seems not too much to hope that through the intravenous administration of strophanthin or pure digitalis glucosides, it may in the future be possible to arrive at the actual production of this or other 
especially desired effects. Zollinger's experiments on rabbits with artificially produced aortic regurgitation have shown a greater efficiency of the heart, with some increase in the diastolic filling, under digitalis.

E. In Failure of the Right Ventricle.-In the comparatively rare cases of isolated failure of the right ventricle, secondary to advanced emphysema, kyphoscoliosis, and so forth, digitalis is notoriously unsuccessful. In such cases, the dyspnea is dependent as much on the primary disease in the lung as on the cardiac weakness, and therefore cannot be relieved. In addition, as in so many cases of primary myocardial weakness, in aortic disease, and in some of the mitral hearts with normal rhythm, the eventual appearance of general venous congestion is the last stage in a slowly developing disproportion between the ventricular muscle and the demand it is called on to meet. The reserve force of the heart, particularly of the right ventricle, is not unlimited. Where sudden overstrain, or the sudden development of fibrillation upsets the balance, the removal of this additional interference with proper cardiac function may give prompt relief. Where no such deleterious factor enters, we must look on the functional exhaustion as the expression of anatomical lesions so extreme as to be analogous to the surgeon's category of "inoperable cases," and not blame our remedies for failure to help. When in emphysema, the occurrence of an attack of asthma on the other hand leads to acute insufficiency of the right ventricle, I believe from my experience that caffein often acts surprisingly well. Meyer endorses this view.

F. In Exophthalmic Goiter.-In the rapid heart of exophthalmic goiter I have not personally seen any definite effects from digitalis, except when the heart became markedly insufficient, with chronic passive congestion and edema. Then I have known it to act admirably. I have at times thought that the earlier cases were improved by continued small doses of digitalis or strophanthus, but with our present knowledge of the cardiac rhythm, I do not feel that the evidence I accepted can be relied on, and that improvement was not due to other therapeutic measures, mainly rest.

Overdosage.-In all these hearts with regular rhythm I believe that dosage should be more cautious than in the fibrillating hearts. The onset of abnormal rhythm is one guide to toxic effects. Another, which I have always heeded, is the sudden cessation of a previous diuresis. Withering himself made this a guide, and many experienced clinicians have found it of value (Meyer).

\section{DRUGS IN OTHER DISTURBANCES OF RHYTHM}

A. In Paroxysmal Tachycardia.-Practically the same considerations exist in paroxysmal tachycardia. Here it is perfectly clear that we do not possess any drug with which we can definitely cut short the 
paroxysm. I am in agreement with Vaquez that no form of digitalis treatment is indicated, except in very protracted attacks, when evidences of cardiac insufficiency appear, and that then intravenous strophanthin is probably the best form. That in the case cited by Edens, a patient with severe mitral disease as well, who received digitalis for five days without effect and on the sixth had a sudden fall of the rate to onethird, the result can be attributed to the drug taken, is to me most unlikely. The failure even of fibrillating paroxysmal tachycardia to respond to digitalis is one of the most difficult problems awaiting solution in this field. It shows plainly that fibrillation itself is not the sole condition determining the beneficial results of digitalis therapy. It is to be hoped that careful electrocardiographic studies of the effects of large doses of strophanthin intravenously in such attacks will shed light on the present insoluble difficulties.

B. In Heart Block.-The use of cardiac remedies in heart block is a subject about which much apprehension exists, largely because of theoretical considerations. In complete block the inhibitory effects of digitalis are not to be feared, and, as von Tabora's experiments have shown, it is even possible that the idioventricular rhythm may be increased by it. When cardiac insufficiency with venous stasis supervenes on complete block, digitalis is definitely indicated. Like Vaquez and Edens, I have seen great improvement following its use. As Edens remarks, in such cases one can scarcely escape the conclusion that one has observed clinically the definite systolic effects of digitalis. In partial block, Volhard has seen reassociation occur under digitalis; but complete block is so likely to result that it should be experimented with cautiously. I have recently observed such reassociation follow the use of theobromin.

C. In Extrasystolic Irregularity.-The treatment of extrasystolic irregularities is a subject of such complexity at the present time that consideration of it does not seem to me profitable. Certain types are improved by digitalis, as Edens has shown; others may be made worse. Frequent extrasystoles in insufficient hearts always seem to me an indication for caution in the use of digitalis remedies.

\section{DRUGS IN ANGINA PECTORIS}

Closely allied to the symptom-complex presented by many cases of aortic regurgitation, is angina pectoris. Anginoid pain on exertion is evidence of an abnormal function response on the part of the heart, totally different from the syndrome of chronic passive congestion and edema. I believe that the use of the terms "myocardial insufficiency" or "asystole" should be restricted to hearts exhibiting the latter. The lack of a satisfactory theory to explain the mechanism of anginoid pain 
forces us to rely on clinical experience as a guide to its treatment. $\mathrm{My}$ experience, through my association for a number of years in the consulting office of my father, among a class of patients often afflicted with this condition, has given me the opportunity to observe the effect of treatment in many hundreds of such patients. There is not the slightest doubt in my mind that in anginoid pain on exertion, or excitement, which must not be identified completely with the intense, and often fatal, paroxysms of severe angina pectoris, the quickly acting nitrites are the sovereign and almost invariably effective remedies for the relief of the paroxysm. What is more, one may even observe that nitrites administered just before exertion is undertaken will frequently enable these patients to perform double the amount of work of which they would be otherwise capable, and without pain. My preference is for nitroglycerin, which patients can carry with them in fresh tablet form. The tablets must be taken on the tongue, not swallowed. The absorption of nitroglycerin from the mouth takes place as a rule in less than one minute; from the stomach it is much more variable and delayed. Many failures to obtain relief in anginoid pain with nitroglycerin are due to inert drugs, or to the drug being swallowed. Amyl nitrite I do not think is any more effective; it is objectionable because of the odor and the attention this attracts to the patient. All other nitrites act too slowly. In the angina of hypertensive cases, nitroglycerin is peculiarly effective, but it frequently acts well in apparent coronary angina associated with low pressure, and also in the anginal attacks of syphilitic aortitis. In some of these patients very large doses, up to $1 / 10$ grain or more, may be necessary; and the dose is always a matter for individual experiment. The continued administration of the nitrites I do not believe has any great value. From the observation of the blood-pressure during such paroxysms, my feeling is strong that the nitrites do not give relief through their lowering of the aortic blood-pressure, for the relief usually precedes this. I am inclined to regard their favorable action as due to local dilatation of the coronary arteries, though of this one cannot be certain. My personal experience, which is in accord with that of Huchard and of Krehl, is that the continued administration of iodid in small doses is of more value in diminishing the frequency of the paroxysms than any other remedy.

In very severe angina pectoris the nitrites are clearly valueless, and morphin is the strict indication. Here it is possible that digitalis may support the heart, as some of Miller and Matthews' experiments on ligature of the coronary arteries seem to demonstrate. When anginal attacks are followed by dilatation of the heart and myocardial insufficiency of the ordinary type, the attacks regularly disappear. Under such circumstances I have had brilliant results with digitalis, as in any 
other type of insufficient heart. An interesting observation, which has been made by Musser, is that recovery from the ventricular insufficiency under digitalis is frequently followed by recurrence of anginal pain. One is strongly tempted here to believe that the alteration in tone of the wall of the ventricle has been the factor. I have not seen striking results from the use of theobromin as advocated by Askanazy.

VII. THE TREATMENT OF RECENT ENDOCARDITIS AND INITIAL CARDIAC INSUFFICIENCY

The use of digitalis in the very earliest stages of cardiac insufficiency has been urged by Hoffmann and Fraenkel (cited by Meyer), and especially by Romberg. I am inclined to believe in the cautious, persistent use of small doses after convalescence from acute rheumatic endocarditis, in conjunction with physical methods of treatment; but I do not feel certain of the part that digitalis plays in bringing about improvement. In the slight myocardial weakness of obese persons, of anemia, and of convalescence from severe acute illness, I doubt its usefulness. In the earlier stages of decompensation and valvular disease, without fibrillation, I believe the continued use of small doses is ordinarily desirable, not pushing to the point of producing disturbances of rhythm; but until we have better means for measuring the effects of digitalis on other functions than rhythm, scepticism of clinical evidence of improvement in such cases is perfectly legitimate.

A. Circulatory Failure of Acute Infectious Disease.-The treatment of the circulatory failure of acute infectious disease must recognize the predominant part played by the vasomotor system, rather than the heart, in the production of the clinical picture. The clinical syndrome, the asual failure of the pure cardiac remedies, and the experimental demonstrations of Romberg and Pässler show this. Our means of combating extreme vasomotor depression are limited. The ideal drug would be a substance acting like epinephrin, but whose effects were persistent. Such a substance we do not possess. I have seen the most amazing restoration from apparent imminent death follow the intravenous injection of epinephrin in large doses-in one case over 4 c.c. of the 1 to 1,000 solution in a little more than an hour. This was in a case of extensive bronchopneumonia, with extreme cyanosis. Life was prolonged for three days. Only in pneumonia, however, is the fleeting action of epinephrin likely to be of service. Caffein has seemed to me of benefit. Camphor is little used in America. Recent experience at the Rockefeller Institute would seem to indicate that large doses of strophanthin, to the point of toxic effects, may occasionally save life in pneumonia with circulatory failure attended by extreme tachycardia. These experiments have been conducted by Dr. Fraser under absolute electrocardiographic 
control; they will not be published until they are confirmed in a group of cases. The possibilities of danger are considerable, but it is to be hoped that the very thorough studies being carried on will yield a valuable and rational method of treatment. I am quite sure that in these cases digitalis by mouth is worthless, and have myself formerly been in the habit of employing it subcutaneously, which is always painful. I do, however, recognize cases in which the combination of subcutaneous digitalis and caffein has seemed to give clear clinical evidence of combating the circulatory collapse. In so protracted a disease as typhoid fever, I do not believe drugs have any value. As to the efficiency of strychnin, except as a respiratory stimulant, I am in doubt. To be of use, it certainly must be given in large doses.

\section{CONCLUSIONS}

Such a review of the comparative clinical value of cardiac remedies shows how very real has been the progress of pharmacology and therapeutics during recent years. The indications for digitalis therapy have become increasingly precise through the exact study of the cardiac rhythm. One task for the future is the elaboration of equally accurate clinical methods for the estimation of the more fundamental effects of these drugs on the ventricle, and for the analysis of their cardiac and vasomotor actions. That increasing fineness of observation can ever replace the skill and experience of the master clinician, I do not for a moment believe. Withering, depending only on his unaided sight and touch, laid down the main rules for digitalis therapy which we follow to-day. The treatment of disease is an art which will ever require greater practice to master its increasingly elaborate technic, and riper judgment to utilize the growing volume of exact analytical data which scientific methods of clinical observation are furnishing. Methods can never, replace the master.

\section{BIBLIOGRAPHY}

Agassiz, C. D. S.: Observations upon the Effects of Strophanthin in Cases of Auricular Fibrillation, Heart, 1911-12, iii, 353.

Askanazy, A.: Klinisches uber Diuretin, Deutsch. Arch. f. klin. Med., 1896, lvi, 209.

Bailey, Harold C.: A Clinical Study of Crystalline Strophanthin, Jour. Pharmacol. and Exper. Therap., 1909, i, 349.

Boos, W. F., Newburgh, L. H., and Marx, H. K.: The Use of Digipuratum in Heart Disease, The ARchives Int. MEd., 1911, vii, 551.

Braun, Ludwig: Die Experimentelle Grundlage der Digitalis-Caffein-Medication, Ztschr. f. exper. Path. u. Therap., 1905, i, 360.

Brunton, Lauder: Therapeutics of the Circulation, Phila., 1908, Blakiston's Son \& Co., p. 145.

Burnet, J.: Effect of Certain Cardiac Remedies on Arterial Pressure, Med. Press and Circular, 1912, xciv; Abstr., Jour. Am. Med. Assn., 1912, lix, 1222. 
Busquet, H.: Action eardiaque comparée de l'extrait physiologique de digitale et des autres preparations digitaliques, Compt. rend. Acad. d. Sc., 1912, clv, 509; Abstr., Ztschr. f. Chemotherap., part 2, 1912, i, 1215.

Chauffard, A., and Troisier, Jean: Effets utiles et dangers des injections de strophanthine, Bull. et Mém. Soc. méd. d. hôp., Paris, 1909, xxvii, 700 .

Cloetta, M.: On Digalen, Münch. med. Wchnschr., 1904, xxxiii; Ueber den Einfluss der chronischen Digitalisbehandlung anf das normale und pathologische Herz, Arch. f. exper. Path. u. Pharmakol., 1908, lix, 209.

Cow, Douglas: Notes on some New Substitutes for the Galenical Preparations of Digitalis, Biochem. Jour., 1912, vi, 219.

Cushny, A. R.: The Therapeutics of Digitalis and its Allies, Harvey Lectures, 1910-1911, Phila., J. B. Lippincott, p. 46; Treatment of Non-valvular Heart Disease, Brit. Med. Jour., Sept. 21, 1912, 685.

Cushny, A. R., Marris, H. F., Silberberg, M. D.: The Action of Digitalis in Therapeutics, Heart, 1912, iv, 33.

Danielopolu, D.: Recherches sur l'action de la strophantine en injection intravéneuse dans les affections du coeur, Arch. d. mal. du coeur, 1908, i, 624.

Danielopolu, D., Dumitrescu, A., Popescu: La constante uréó-sécrétoire chez les cardiaques asystoliques. Action de la digitale, Compt. rend. Soc. de Biol., 1913 , lxxiv, 295.

Dixon, W. E.: Critical Review. The Digitalis Preparations employed in Medicine, Quar. Jour. Med., 1911, v, 297.

Edens, E.: Ueber Digitaliswirkung, Deutsch. Areh. f. klin. Med., 1911, civ, 512.

Edmunds, C. W., and Hale, W.: The Physiological Standardization of Digitalis, Bull. Hyg. Lab., U.S.P.H.S., 1908, No. 48.

Figgleston, Cary: Clinical Observations on the Duration of Digitalis Action, Jour. Am. Med. Assn., 1912, Iix, 1352.

Fahrenkamp, Carl: Ueber die verschiedene Beeinflussung der Gefässgebiete durch Digitoxin, Arch. f. exp. Path̀. u. Pharmakol., 1911, lxv, 367.

Focke: Ueber den gleichmässigen Wirkungswert von gut präpariertem und gut aufbewahrtem Digitalispulver, Therap. d. Gegenw., 1904, vi (N. F.) ; 250.

Fraenkel, Albert: Chronische Herzinsuffizienz und intravenöse Strophanthintherapie, Münch. med. Wchnschr., 1912, lix, 289; Bemerkungen zur internen Digitalismedikation. Arch. f. exp. Path. u. Pharmakol., 1907, Ivii, 131; Ueber Digitalistherapie, Ergeb. d. inn. Med. u. Kinderh., 1908, i, 68; Zur Frage der Kumulation, insbesondere beim Digalen, Arch. f. exp. Path. u. Pharmakol., 1907, lvii, 123.

Fraenkel, A., and Schwartz, G.: Ueber Digitaliswirkung an Gesunden und an kompensierten Herzkranken, Arch. f. exp. Path. u. Pharmakol., 1908, lix, 188; Ueber intravenöse Strophanthininjektionen bei Herzkranken, Arch. f. exp. Path. u. Pharmakol., 1907, lvii, 79.

Gelbart, Moses: Ueber den Einfluss der Digitalis auf frisch entstandene Klappenfehler, Arch. f. exp. Path. u. Pharmakol., 1911, lxiv, 167.

Gibson, Alexander G.: A Contribution to the Knowledge of the Action of Digitalis on the Human Heart, Quar. Jour. Med., 1907-8, i, 173.

Gottlieb, R.: Ueber Herzmittel und Vasomotorenmittel, XIX Kongr. f. inn. Med., 1901, 21; Haben therapeutische Digitalisgaben Gefässwirkung? Therap. Monatseh., 1912, xxvi, 479.

Gottlieb, R., and Magnus, R.: Ueber die Gefässwirkung der Körper der Digitalisgruppe, Arch. f. exp. Path. u. Pharmakol., 1902, xlvii, 135.

Gottlieb, R., and Ogawa, S.: Ueber die Resorption von Digitoxin aus Digitalispräparaten und uber ihre Beziehung zu Wirkung und Nebenwirkungen derselben, München. med. Wchnschr., 1912, lix, 2265, 2339.

Gottlieb, R., and Tambach, R.: Ueber Digipuratum, München. med. Wchnschr., 1011, lviii, 10.

Hale, W.: Digitalis Standardization and the Variability of Crude and of Medicinal Preparations, Bull. Hyg. Lab., U.S.P.H.S., 1911, No. 74. 
Hare, H. A., and Coplin, W. M. L.: The Influence of Digitalis on the Heart Muscle When the Drug is Administered for a Long Time, Therap. Gaz., Detroit, 1897 , xxi, 800 .

Hartung, C.: Ueber Digifolin, ein neues Digitalispräparat, München. ned. Wchnschr., 1912, lix, 1944.

Hatcher, Robert A.: The Absorption, Excretion, and Destruction of Strophanthin, Am. Jour. Physiol., 1909, xxiii, 303; The Persistence of Action of the Digitalins, The Archives Inr. Med., 1912, x, 268; Note on Strophanthin, Jour. Am. Med. Assn., 1910, liv, 1050.

Hatcher, Robert A., and Bailey, Harold C.: Tincture of Strophanthus and Strophanthin, Jour. Am. Med. Assn., 1909, lii, 5; The Clinical Use of Strophanthus, Jour. Am. Med. Assn., 1910, lv, 1697.

Hatcher, Robert A., and Eggleston, Cary: The Emetic Action of the Digitalis Bodies, Jour. Pharmacol. and Exper. Therap., 1912, iv, 113.

Hedinger, Max: Uber die Wirkungsweise von Nieren- und Herzmitteln auf kranke Nieren, Deutsch. Arch. f. klin. Med., 1910, c, 305; Ueber die Wirkungs. weise von Nieren- und Herzmitteln bei nierenkranken Menschen, München. med. W chnschr., 1912, lix, 1098; Experimentelle Studien über die Wirkungsweise von Nieren- und Herzmitteln auf kranke Nieren, Kongr. f. inn. Med., 1910, xxvii, 750.

Henrijean, F.: Traitement de la bradycardie par la digitale, Congr. de Méd., 1910; Abstr., Arch. d. mal. du coeur, 1910, 740.

Heubner, W.: Das Wesen der Digitaliswirkung, Therap. Monatsch., 1912, xxvi, 157.

Hewlett, Albion W.: Heart Block in the Ventricular Walls, The Archives INT. MED., 1908, ii, 139.

Hewlett, Albion W., and Barringer, T. B.: 'The Effect of Digitalis on the Ventricular Rate in Man, The ARcinves Int. Med., 1910, v, 93.

Hochheim, K.: Klinisches und Experimentelles über g-Strophanthin Thoms, Centralbl. f. inn. Med., 1906, xxvii, 65.

Hoffmann, August: Funktionelle Diagnostik und Therapie der Erkrankungen des Herzens und der Gefässe, Wiesbaden, 1911, J. F. Bergmann, p. 406.

Holste, Arnold: Ueber die Bestimmung des pharmakologischen Wirkungswertes der Blätter von Digitalis purpurea, Arch. f. exp. Path. u. Pharmakol., 1911 , lxvi, 161 .

Huchard, H.: Les maladies du coeur et leur traitment, Paris, 1908, J. B. Baillière et fils.

Janeway, Theodore C.: The Use and Abuse of Digitalis, Am. Jour. Med. Sc., 1908 , exxxv, 781 .

Jonescu, D., and Loewi, O.: Ueber eine spezifische Nierenwirkung der Digitaliskörper, Arch. f. exp. Path, u. Pharmakol., 1908, lxix, 71.

Josue, O., and Godlewski, Henri : Pression artérielle et digitaline, Bull. et mém. Soc. méd. d. hôp., 1912, xxviii, 480 .

Kasztan, Max: Beiträge zur Kenntnis der Gefässwirkung des Strophanthins, Arch. f. exp. Path. u. Pharmakol., 1910, lxiii, 405.

Kauffmann, Rudolf: Ueber den Einfluss des Schmerzes und der Digitalis auf die Herzarbeit des normalen Menschen, Ztschr. f. exp. Path. u. Therap., 1913, xii, 165 .

Kobert, R.: Ueber die wirksamen Bestandteile und die Verordungsweise der Digitalis, München. med. Wchnschr., 1912, lix, 1864.

Krafft, F.: Die Glykoside der Blätter von Digitalis purpurea, Arch. d. Pharmakol., 1912, ccl. 118; Abstr., Therap. Monatsch., 1912, xxvi, 822.

Krehl, L.: Diseases of the Myocardium and Nervous Diseases of the Heart, in Nothnagel's Practice of Medicine, Am. ed., Phila., W. B. Saunders, 1908, p. 543.

Laslett, E. E.: Sinus Arrhythmia of High Grade Induced by Digitalin, Quart. Jour. Med., 1911, v, 377.

Lewis, Thomas: The Reaction of the Heart to Digitalis When the Auricle is Fibrillating, Brit. Med. Jour., 1910, Nov. 20, 1670; Auricular Fibrillation and 
its Relation to Clinical Irregularity of the Heart, Heart, 1909-10, i, 306 ; Observations upon Disorders of the Heart's Action, Heart, 1911-12, iii, 279.

Lewy, Benno: Die Arbeit des gesunden und des kranken Herzens, Ztschr. f. klin. Med., 1897, xxxi, 520.

v. Lhota, C. L.: Untersuchungen über das Verhalten der Digitalisstoffe im Körper, besonders bei der Angewöhnung an dieselben, Arch. internat. de Pharmacol., 1912, xxii, 61 ; Abstr., Therap. Monatsch., 1912, xxvi, 890.

Longeope, W. T.: Syphilitic Aortis: Its Diagnosis and Treatment, Th⺊ ARChIVes Int. Med., 1913, xi, 15.

Mackenzie, James: Digitalis, Heart, 1910-11, ii, 273; General Treatment of Diseases and Affections of the Heart, in A System of 'Treatment, ed. by Arthur Latham and T. C.: English, London, 1912, J. and A. Churchill, pp. 1194-1254.

Meyer, Arthur W.: Die Digitalis-Therapie, Jena, Gustav Fischer, 1912.

Meyer, Felix : Hat g-Strophanthin eine Einwirkung auf den Koronarkreislauf?, Med. Klinik, 1912, viii, 869.

Miller, Jos. L.: Some Clinical Observations on the Drug Treatment of Edema, Tr. Assoc. Am. Phys., 1912, xxvii, 137; Am. Jour. Med. Sc., 1912, cxliv, 8.

Miller, Jos. L., and Matthews, S. A.: Preliminary Report on Experimental Ligation of the Coronary Arteries, Tr. Assoc. Am. Phys, xxiii, 83.

Musser, John H.: Angina Pectoris: Its Relation to Dilatation of the Heart, Tr. Assoc. Am. Phys., 1897, xii, 70.

Ugawa, S.: Ueber die Resorption wirksamer Bestandteile aus Digitalisblättern und Digitalispräparaten, Deutsch. Arch. f. klin. Med., 1912, cviii, 554.

Pratt, J. H.: On the Importance of Determining the Potency of Digitalis Preparations, Bost. Med. and Surg. Jour., 1910, clxiii, 279.

Price, F. W.: Some Investigations of the Action of Digitalis on the BloodPressure in Man, Brit. Med. Jour., 1912, Sept. 21, 689.

Rihl, J.: Analyse von fünd Fïllen von Ueberleitungsstörungen, Ztschr. f. exp. Path. u. Therap., 1905, ii, 83.

Romberg, Ernst: Ueber Digitalis, München. med. Wchnschr., 1913, 1x, 1.

Romberg, E., und Pässler, H.: Experimentelle Untersuchungen über die allgemeine Pathologie und Therapie der Kreislaufsstörung bei akuten Infektionskrankheiten, Deutsch. Arch. f. klin. Med., I899, lxiv, 652.

Sahli, 1I.: Ueber Herzmittel und Vasomotorenmittel, XIX Kongr. f. inn. Med., $1901,45$.

Schlayer: Ueber die Ermüdbarkeit der Nierenfunktion, XXIX Kongr. f. inn. Med., 1912, 500.

Schlayer und Hedinger: Experimentelle Studien über toxische Nephritis, Deutsch. Arch. f. klin. Med., 1907, xc, 1.

Schmiedeberg, O.: Untersuchungen ïber die Bestimmung des pharmakologischen Wirkungswertes der getrockneten Blätter von Digitalis purpurea, Arch. f. exp. Path. u. Pharmakol., 1910, lxii, 305.

Schrenk, Theophil: Ueber die Wirkung der Digitalis auf die verschiedenen Formen von Herzerkrankung, München. med. Wchnschr., 1912, lix, 2908.

Straub, Walther: Dynamik des Froschherzventrikels bei nichttödtlicher Digitalisvergiftung, Ztschr. f. exp. Path. u. Pharmakol., 1905, i, 489.

Tabora, von: Ueber die experimentelle Erzeugung von Kammersytolenausfall und Dissociation durch Digitalis, Ztschr. f. exp. Path. u. Therap., 1906, iii, 499.

'Taussig, Albert E.: Complete and Permanent Heart-block following the Use of Digitalis in Auricular Fibrillation, The Akchives Int. Med., 1912, x, 335.

Vaquez, H.: Les arythmies, Paris, Baillière, 1911.

Vaquez et Leconte: Les injections intraveineuses de strophanthine dans le traitement d l'insuffisance cardiaque, Bull. et. mêm. Soc. méd. d. hôp, Paris, 1909, xxvii, 662.

Veiel, E.: Ueber Digipuratum Knoll, München. med. Wchnschr., 1910, lvii, 2046. 
Volhard, F.: Ueber die Beziehungen des Adams-Stokes'schen Symptomenkomplexes zum Herzblock, Deutsch. Arch. f. klin. Med., 1909, xevii, 348.

Weis, Edmund: Ueber den physiologischen Wirkungswert einiger Digitalispräparate, Osterr. Sanitätswesen, 1912, xxiv, Beilage, 162; Abstr., Therap. Monatsch., 1912, xxvi, 662.

Werschinin, N.: Zur Kenntnis der diastolisehen Herzwirkung der Digitalingruppe, Arch. f. exp. Path. u. Pharmakol., 1909, lx, 328.

Williams, Francis: Ueber die Ursache der Blutdrucksteigerung bei der Digitalinwirkung, Arch. f. exp. Path. u. Pharmakol., 1881, xiii, 1.

Windle, J. Davenport: Heart-block from Drugs of the Digitalis Group, Heart, 1911-12, iii, 1 .

Wynn, Frank B.: Will the Long-continued Administration of Digitalis induce Cardiac Hypertrophy? Jour. Am. Med. Assn., 1904, xliii, 164.

Zollinger, Fr.: Zur experimentellen Pathologie und Therapie der akuten Aorteninsuffizienz, Arch. f. exper. Path. u. Pharmakol., 1909, lxi, 193. 